\title{
Pelatihan Internet dan Power Point untuk Guru-Guru di Sekolah Dasar 23 Kota Sabang
}

\author{
Munawir $^{1 *}$, Syamsul Rizal ${ }^{2}$, Abdus Salam ${ }^{3}$, Ismail ${ }^{4}$ \\ 1,3,4 Program Studi Manajemen Informatika, Fakultas Ilmu Komputer, \\ AMIK Indonesia, Jl. T Nyak Arief Sp Mesra No. 400, Kota Banda Aceh, Indonesia \\ 2 Program Studi Keuangan dan Perbankan, Fakultas Ekonomi, \\ Akademi Keuangan Perbankan Nusantara, Jl. Medan-Banda Aceh, Kabupaten Aceh Timur, Indonesia \\ Email:munawir@amikindonesia.ac.id¹,syamsulrizal@akubanknusantara.ac.id², \\ abdussalam@amikindonesia.ac.id ${ }^{3}$, ismail@amikindonesia.ac.id ${ }^{4}$
}

\begin{abstract}
Abstrak
Kebutuhan orang untuk memanfaatkan fasilitas email internet semakin meningkat, seiring dengan pertumbuhan internet yang ada di instansi-instansi baik pemerintah maupun non pemerintah. Di SD ada beberapa yang telah memiliki jaringan internet sebagai sarana koneksitas dengan dunia luar. Namun beberapa kendala masih ada mengingat persentase guru yang mampu memanfaat internet dan power point masih kecil. Seperti dicontohkan di SD N 23 Kota Sabang, hanya sekitar 2 orang guru yang biasa memakai internet dan power point, sedang guru lainnya belum bisa mengoperasikan internet. Sasaran dalam program pengabdian ini adalah meningkatkan kemampuan dan kompetensi guru-guru di SD N 23 Kota Sabang dalam menerapkan teknologi informasi yaitu dengan pelatihan internet sehingga mampu memanfaatkan sarana yang ada di internet untuk kepentingan komunikasi (E-mail), serta meningkatkan kemampuan dan kompetensi guru dalam media pembelajaran melalui pelatihan power point untuk sarana presentasi. Berdasarkan hasil pengamatan dan evaluasi terlihat guru-guru mengikuti pelatihan dengan sangat antusias. Pelatihan internet dan power point ini telah dilaksanakan selama 2 hari yaitu pada tanggal 29 Agustus 2014 dengan jumlah peserta 10 guru, dan tanggal 31 Agustus 2014 dengan jumlah peserta 10 guru. Guru yang mengikuti program pelatihan ini memiliki disiplin ilmu yang berbeda-beda sesuai dengan bidang keahlian dan mata pelajaran yang diampunya. Selama 2 hari tersebut, pada hari pertama peserta yaitu para guru SD N 23 Kota Sabang telah berhasil mempraktikkan materi internet yaitu Browsing, Searching, Downloading, dan Email. Pada hari kedua, peserta juga telah berhasil mempraktikkan materi power point dengan membuat tulisan, membuat rancangan tampilan, mengatur animasi tampilan untuk presentasi.
\end{abstract}

Kata Kunci: Jaringan Internet, Pelatihan; Powerpoint; Teknologi Informasi.

\section{Pendahuluan}

Pendidikan sebagai bagian dari sistem kehidupan di masyarakat tidak dapat dilepaskan dari perkembangan dan perubahan yang terjadi di masyarakat itu sendiri. Perubahan struktur dunia kerja yang diakibatkan pesatnya perkembangan ilmu pengetahuan dan teknologi serta diberlakukannnya era global menuntut lembaga pendidikan untuk benar-benar menghasilkan lulusan yang berkualitas dan memiliki daya saing kuat. Dalam era global dan perkembangan iptek yang begitu cepat, pendidikan tinggi dihadapkan pada bebagai permasalahan menyangkut kualitas lulusan yang dihasilkan. Dari dunia usaha/industri muncul keluhan bahwa lulusan yang memasuki dunia kerja belum memiliki kesiapan kerja yang baik [1].

Perubahan struktur dunia kerja yang begitu cepat seiring pesatnya perkembangan ilmu pengetahuan dan teknologi menuntut tersedianya tenaga kerja yang berkualitas, mandiri dan produktif [2,3]. Perguruan tinggi sebagai bagian dari pendidikan memiliki peran stragegis dalam menunjang pengembangan teknologi dan ilmu pengetahuan. Namun demikian dalam menjalankan 
misi sebagai lembaga pendidikan tinggi harus mampu mengikuti perkembangan teknologi dan informasi untuk mereduksi ketinggalan atau diskomunikasi dengan dunia luar. Perkembangan tentang informasi dan teknologi sangat penting mengingat setiap tahun atau bahkan setiap bulan ilmu pengetahuan dan informasi selalu berkembang.

Perkembangan informasi dan teknologi dari dunia luar salah satunya dapat di akses melalui situs situs internet [4]. Perkembangan yang meliputi teknologi, sains, kebudayaan, seni, pendidikan, dsb dapat dapat diakses melalui jaringan internet [4,5]. Bahkan komunikasi semakin mudah dengan memanfaatkan e-mail, yang saat sekarang sedang trend. E-mail memiliki kelebihan dapat mengirimkan pesan sampai mengirimkan file data komputer dengan cepat dan tentu biaya yang murah.

Kebutuhan orang untuk memanfaatkan fasilitas email internet semakin meningkat, seiring dengan pertumbuhan internet yang ada di instansi-instansi baik pemerintah maupun non pemerintah. Di SD ada beberapa yang telah memiliki jaringan internet sebagai sarana koneksitas dengan dunia luar. Namun beberapa kendala masih ada mengingat persentase guru yang mampu memanfaat internet dan power point masih kecil. Seperti dicontohkan di SD N 23 Kota Sabang, hanya sekitar 2 orang guru yang biasa memakai internet dan power point, sedang guru lainnya belum bisa mengoperasikan internet $[6,7,8]$.

Untuk mencoba mengatasi permasalahan di "SDN 23 KOTA SABANG" tersebut maka dilakukan pelatihan internet dan power point yang di ikuti oleh guru-guru dari SD tersebut. Dengan pelatihan ini diharapkan guru mampu menggunakan internet dan power point untuk keperluan penyerapan dan pengembangan ilmu pengetahuan serta memanfaatkan internet sebagai sarana komunikasi dan power point untuk media presentasi.

\subsection{Tujuan Kegiatan}

Tujuan kegiatan ini adalah untuk melatih menggunakan internet dan power point untuk guruguru di "SDN 23 Kota Sabang" sehingga mampu memanfaatkan sarana yang ada di internet untuk kepentingan komunikasi (E-mail) maupun power point untuk sarana presentasi.

\subsection{Manfaat Kegiatan}

Manfaat yang diharapkan dari pelatihan ini adalah guru yang ada di tingkat SD mampu menularkan pengetahuan yang diperoleh dari internet dan power point kepada anak didik yang berimbas pada peningkatan kualitas SDM lulusan SD tersebut.

\section{Realisasi Kegiatan}

\subsection{Bentuk Kegiatan \& Jadwal, Serta Tempat Kegiatan}

a. Metode Pelaksanaan Kegiatan

Metode pelaksanaan kegiatan pengabdian terdiri dari Ceramah dan Tanya Jawab, Demonstrasi, dan Pelatihan dan Praktek.

\section{b. Waktu Efektif Pelaksanaan Kegiatan}

Kegiatan Pelaksanaan Pengabdian Kepada Masyarakat ini dilakukan pada awal Agustus 2014.

\section{c. Tempat Kegiatan}

Lokasi pengabdian ini pada SD N 23 Kota Sabang yang beralamat pada Kelurahan Batee Shok Kecamatan Sukakarya Kota Sabang. 


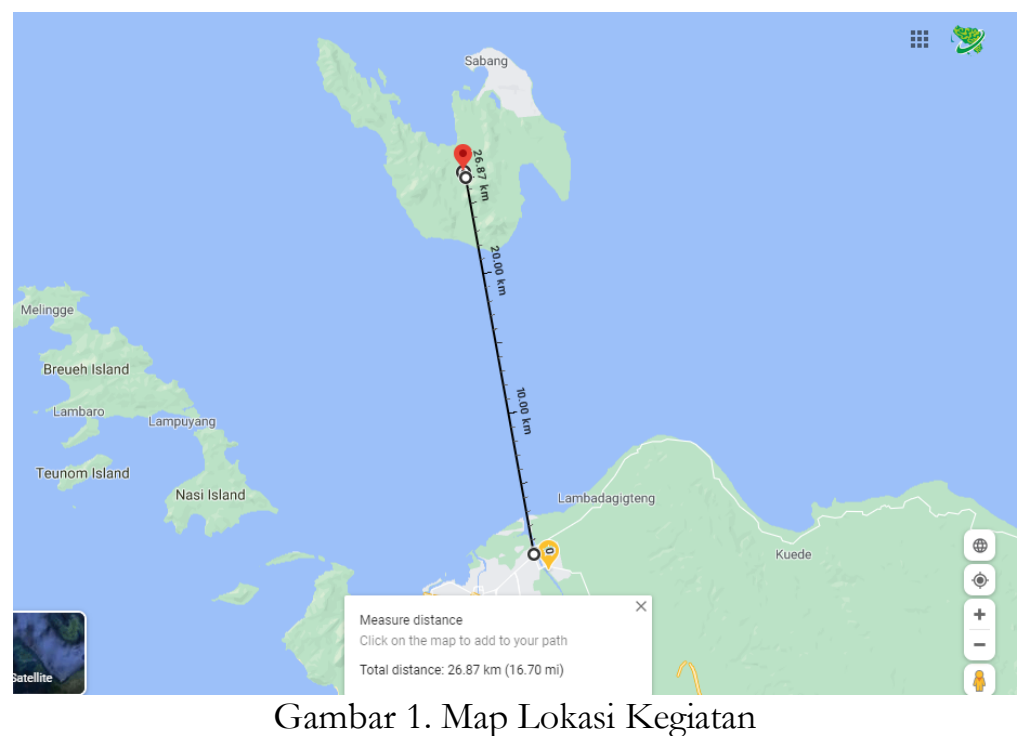

\subsection{Hasil Pelaksanaan Pengabdian}

Bentuk langkah-langkah kongkrit yang dilaksanakan dalam pelatihan ini sehingga pelatihan ini dapat berhasil dilaksanakan adalah sebagai berikut :

a. Melakukan identifikasi jaringan internet dan identifikasi materi power point dilakukan dengan menanyakan langsung kepada Kepala Sekolah dan Guru ketua lab komputer yang ada di SD N 23 Kota Sabang. Dari keterangan yang disampaikan, Jaringan internet dapat digunakan dengan memakai jaringan Parabola Indosat, dan dihubungkan dengan kabel LAN untuk semua komputer. Komputer yang dipunyai sekolah ini berjumlah 5 buah dengan spesifikasi Prosesor IP 4 dengan RAM 512 MB. Sedangkan materi power point yang diminta pihak sekolah adalah untuk memanfaatkan beberapa "Viewer" untuk pembelajaran.

b. Melakukan pelatihan internet dan power point dengan panduan modul

Pemakaian modul dalam pelatihan ini telah kami terapkan pada pelatihan ini. Modul yang kami siapkan sudah digandakan sekitar 20 buah baik materi internet maupun power point.

c. Pemantauan dan diskusi pemecahan masalah

Pemanatauan dan diskusi telah dilaksanakan pada saat pelaksanaan pelatihan dilaksanakan. Banyak pertanyaan yang di ajukan oleh peserta, dan mereka umumnya meminta untuk didampingi secara individu agar cepat menguasai materi yang disampaikan. Pendampingan ini dilaksanakan oleh 2 orang, dan peserta yang mengikuti pelatihan sekitar 10 orang.

Berdasarkan pengamatan dan evaluasi yang dilakukan selama pelatihan, dapat dilaporkan bahwa kegiatan PPM yang bertempat di SD N 23 Kota Sabang telah berhasil dilaksanakan dengan materi pelatihan internet dan power point yang dilaksanakan selama 2 hari (10 jam). Indikator keberhasilan yang telah dicapai dalam pelatihan ini daat dilihat dari pencapaian kompetensi guru (peserta pelatihan) yang dilihat dari pengamatan selama proses pelatihan, yaitu:

a. Peserta dapat melakukan browsing dan searching melalui fasilitas pencarian internet yaitu www.google.com dan www.yahoo.com

b. Peserta dapat mengenal situs-situs penting di internet dan dapat men-download file-file secara free.

c. Peserta dapat membuat, mengirim dan mengirim pesan melalui e-mail yahoo.com.

d. Peserta dapat membuat tulisan, membuat rancangan tampilan, mengatur animasi tampilan pada program power point untuk kebutuhan presentasi.

\subsubsection{Faktor Pendukung}

Faktor pendukung dalam melaksanakan program pelatihan ini adalah adanya dukungan dana dari pihak AMIK Indonesia serta sudah adanya lab komputer yang sudah dilengkapi jaringan intermet yang ada di SD N 23 Kota Sabang. Hal lain yang juga sangat mendukung adalah motivasi guru-guru 
SD N 23 Kota Sabang dalam mengikuti pelatihan yang terbukti lebih dari $50 \%$ guru dilingkungan SD ini mengikuti pelatihan ini. Disamping itu di Jurusan Manajemen tersedia tenaga ahli yang sudah banyak memanfaatkan internet dan power point dalam proses Pengajaran (PBM).

\subsubsection{Faktor Penghambat}

Secara prinsip tidak ditemukan faktor penghambat yang berarti. Namun yang menjadi sedikit hambatan adalah jadwal pelaksanaan yang harus menyesuaikan dengan kesibukan dari tim PPM (dosen AMIK Indonesia) dan kesibukan dari bapak-ibu guru di SD N 23 Kota Sabang, serta masih menunggu jaringan internet yang pada waktu itu belum dapat digunakan.

\subsubsection{Evaluasi}

Berangkat dari pentingnya peranan internet dalam mengembangkan ilmu pengetahuan dan informasi yang sedang berkembang dan pentingnya power point dalam mengembangkan media pembelajaran untuk meningkatkan kualitas Proses Belajar Mengajar (PBM), maka dilakukan program PPM tentang penggunaan internet dan power point. Sasaran yang dikenai secara langsung adalah guru-guru di lingkungan SD N 23 Kota Sabang, sedangkan secara tidak langsung adalah murid-murid di SD tersebut.

Pelatihan ini dilaksanakan dengan 2 orang instruktur dari Tim PPM dan 1 orang Dosen yang memiliki kompetensi bidang Internet. Materi yang diberikan disampaikan dengan Viewer, dengan panduan modul (modul internet dan modul power point) yang dibagikan ke guru-guru, untuk mempermudah menangkap materi yang disampaikan instruktur. Teknik pelaksanaan, dari 2 instruktur tersebut, 1 orang menjelaskan materi dengan menyorotkan melalui Viewer, sedang 1 instruktur yang lain melakukan pendampingan langsung kepada guru-guru yang sedang mempraktikkan materi pada komputer. Instruktur pendamping berkuajiban mengarahkan materi dikomputer guru tentang hal-hal yang belum jelas atau yang ditanyakan. Dari pengamatan hasil pelatihan internet dan power point, terlihat guru-guru mengikuti pelatihan dengan sangat antusias. Hal ini juga terlihat setiap ada hal yang belum jelas disampaikan instruktur, guru langsung menanyakan kepada instruktur, terutama kepada instruktur pendamping. Beberapa kesulitan kecil, sebagian kecil guru belum begitu mengenal komputer, sehingga harus mengajari dulu dasar-dasar komputer.

Dari materi yang disampaikan melalui modul, masih banyak yang belum jelas secara detail fungsi-fungsi icon pada layar komputer baik program internet maupun power point. Namun hal ini diatasi dengan menjelaskan secara umum fungsi icon-icon yang sering dipakai pada kedua program komputer tersebut. Dari keseluruhan materi yang disampaikan, sekitar $90 \%$ materi materi internet dan $100 \%$ materi power point yang ada dimodul sudah disampaikan dan dipraktikkan oleh guruguru. Dengan demikian diharapkan materi yang sudah dipraktikkan dapat diserap dan dimengerti oleh guru, yang nantinya dapat disampaikan ke anak didik (murid). Adapun materi yang belum dipraktikkan didalam pelatihan (mengingat keterbatasan waktu) seperti tampilan menu, contohcontoh situs, para guru dapat mempraktikkan di waktu yang lain dengan acuan modul yang sudah diberikan.

Selama 2 hari tersebut, pada hari pertama peserta yaitu para guru SD N 23 Kota Sabang telah berhasil mempraktikkan materi internet yaitu Browsing, Searching, Downloading, dan E-mail. Pada hari kedua, peserta juga telah berhasil mempraktikkan materi power point dengan membuat tulisan, membuat rancangan tampilan, mengatur animasi tampilan untuk presentasi. Melihat dari pentingnya internet dan power point untuk pengembangan sekolah baik SD maupun SMA, maka sekolah yang telah memiliki jaringan komputer ke internet perlu diadakan pelatihan seperti ini, sehingga pemanfaatan fasilitas yang sudah tersedia disekolah tersebut dapat dimanfaatkan semaksimal mungkin untuk mendukung kualitas SDM maupun kualitas PBM disekolah tersebut.

\subsection{Masyarakat Sasaran}

Adapun ruang lingkup utama dari kegiatan pengabdian kepada masyarakat ini adalah untuk meningkatkan mutu tenaga pengajar terutama dalam bidang komputer dan media pembelajaran, maka program pelatihan internet dan power point ini sangat membantu dan berpartisipasi. Adapun sumbangan yang dapat diberikan dalam membantu guru-guru di SD N 23 Kota Sabang ini adalah 
meningkatkan kemampuan dan kompetensi guru dalam menerapkan teknologi informasi yaitu dengan pelatihan internet sehingga mampu memanfaatkan sarana yang ada di internet untuk kepentingan komunikasi (E-mail), serta meningkatkan kemampuan dan kompetensi guru dalam media pembelajaran melalui pelatihan power point untuk sarana presentasi

\section{Tinjauan Hasil yang dicapai}

a. Tim PPM dari AMIK Indonesia telah berhasil melaksanakan program pelatihan internet dan power point di SD N 23 Kota Sabang.

b. Sekolah SD N 23 Kota Sabang yang telah memiliki jaringan internet memerlukan pelatihan internet dan power point sebagai upaya meningkatkan kualitas guru.

c. Guru- guru di SD N 23 Kota Sabang memberikan tanggapan yang antusias pada pelatihan ini dilihat dari jumlah kehadiran guru maupun respon saat pelatihan.

d. Terjalin kemitraan dan kerjasama antara pihak AMIK Indonesia dan SD N 23 Kota Sabang.

\section{Daftar Pustaka}

[1] Depdiknas. 2002. Konsep pendidikan berorientasi kecakapan hidup (life skill) melalui pendekatan pendidikan berbasis luas (broad based education-BBE), Jakarta: Depdiknas.

[2] Austin, Dennis. "Beginning of PowerPoint: A Personal Technical Story". Diakses tanggal 23 August 2020.

[3] Atkinson, Max. 2014. "The problem with PowerPoint". BBC News.

[4] Gaskins, Robert. 1984. "Sample Product Proposal: presentation graphics for overhead projection" (PDF). Diakses tanggal 19 August 2014.

[5] Kurniawan, A. 2007. MS Office Powe Point 2007, Bandung : P.T. Pradnya Paramita.

[6] Pardosi, M. 2003. Pengenalan Internet, Bandung : P.T. Pradnya Paramita.

[7] Pardosi, M. 2005. Sistem Operasi Windows XP, Bandung : P.T. Pradnya Paramita.

[8] Oentoro. 1998. Prospek perkembangan dunia usaha/industri di Indonesia awal abad dua puluh satu. Makalah Seminar Nasional 10 Oktober 2000. Yogyakarta: FPTK IKIP Yogyakarta. 